\title{
Passion Fruit Quality under Acidic Soil Conditions
}

\author{
Shota Niwayama and Hirokazu Higuchi*
}

Graduate School of Agriculture, Kyoto University, Sakyo, Kyoto 606-8502, Japan

The suitable soil pH for passion fruit growth has been well studied; however, the optimal soil pH for producing high-quality fruit has not been determined. In this study, the effects of soil acidity on fruit quality were determined. One-year-old passion fruit plants were grown in pots filled with soil adjusted to four pH levels (pH 3.5, 4.5, 5.5, and 6.5). The numbers of flowers and fruits were counted, and the external appearance and juice quality of the harvested fruits was evaluated. Vegetative growth, physiological responses, and leaf mineral contents were also measured. At $\mathrm{pH} 4.5$ and 5.5, fruit were heavier and larger, with a better peel color than the fruit at pH 3.5 and 6.5. As indicators of taste, the titratable acid content was lower and total soluble solid content was higher at $\mathrm{pH} 4.5$ and 5.5, indicating preferable palatability. The sugar/acid ratio was highest at pH 4.5. The numbers of flowers and fruits, vegetative growth, and photosynthetic rate were also higher at pH 4.5 and 5.5. Conversely, soil with a near-neutral $\mathrm{pH}$ of 6.5 yielded fruit with a pale peel color, severe peel wrinkles, and a low sugar/acid ratio. Vegetative growth was inhibited, and the photosynthetic rate and leaf water potential were lowest at $\mathrm{pH}$ 6.5. The leaf/fruit ratio was lower at $\mathrm{pH}$ 6.5. A shortage of photosynthate may have reduced fruit quality. Leaf nitrogen, manganese, and zinc contents, as well as the chlorophyll content (SPAD index), were lowest at pH 6.5. Deficiencies in these minerals may have led to a low photosynthetic rate and SPAD index under the higher $\mathrm{pH}$ condition. With excessive acidic soil (pH 3.5), vegetative growth, photosynthetic rate, and the number of flowers were as high as those at $\mathrm{pH} 4.5$, although the fruit-set percentage and fruit quality were lower. Thus, strongly acidic soil around $\mathrm{pH} 4.5$ is recommended for producing high-quality passion fruit.

Key Words: mineral contents, Passiflora, soil $\mathrm{pH}$, vegetative growth.

\section{Introduction}

Soil $\mathrm{pH} 5.5-7.5$ has been thought suitable for passion fruit cultivation; e.g. 5.5-6.0 (Gilmour, 1983), 5.5-6.5 (Deshmukh et al., 2017), 5.5-6.8 (Nakasone and Paull, 1998), and 6.5-7.5 (Morton, 1987). Kondo et al. (2017) cultivated passion fruit in soils with various $\mathrm{pH}$ values (pH 4.7, 5.4, 6.8, and 7.4), however, and noted that the photosynthetic rate, SPAD index, and leaf nitrogen $(\mathrm{N})$ and phosphorus $(\mathrm{P})$ contents increased in acidic soils ( $\mathrm{pH} 4.7$ and 5.4), and that vegetative growth decreased in alkaline soil ( $\mathrm{pH} 7.4)$, concluding that passion fruit prefers acidic soils. Similarly, Niwayama and Higuchi (2018) reported that strongly acidic soil with $\mathrm{pH} 3.5$

Received; February 5, 2018. Accepted; September 5, 2018.

First Published Online in J-STAGE on October 26, 2018.

A part of this study was presented at the 122nd meeting of Japanese Society for Tropical Agriculture (21-22 October, 2017. Kagawa, Japan).

No conflicts of interest declared.

* Corresponding author (E-mail: higuchi@kais.kyoto-u.ac.jp). promoted the recovery of root growth after pruning roots in half, which may promote vegetative growth in passion fruit. Therefore, strongly acidic soil can be suitable for passion fruit vegetative growth.

In some species, fruit quality is affected by rhizospheric $\mathrm{pH}$ levels. For example, in the Valencia orange, the Brix sugar content increased as soil $\mathrm{pH}$ decreased, and acid content was highest at a soil $\mathrm{pH}$ of 4.0 (Anderson, 1971). Meanwhile, the sugar content of highbush blueberries grown in a solution culture with a $\mathrm{pH}$ of 3.5 was higher than that with a $\mathrm{pH}>4.5$ (Katakura and Yokomizo, 1995). Similarly, strongly acidic soil possibly increases passion fruit vegetative growth and photosynthate, and may improve fruit quality. An increase in photosynthate resulted in a low acid content in passion fruit juice (Kondo and Higuchi, 2011). However, the optimal soil $\mathrm{pH}$ for high quality fruit remains unknown.

In this study, to clarify the effects of soil acidity on passion fruit quality, passion fruit vines were transplanted into soils with different $\mathrm{pH}$ values $(\mathrm{pH} 3.5,4.5$, 
5.5, and 6.5), and the juice quality and external fruit appearance were evaluated. Vegetative growth, the numbers of flowers and fruits, and leaf mineral contents were also examined to assess the factors affecting fruit quality.

\section{Materials and Methods}

\section{Plant materials}

One-year-old hybrid passion fruit (Passiflora edulis Sims $\times$ P. edulis Sims f.flavicarpa Deg. 'Summer Queen') plants were grown in a greenhouse at Kyoto University $\left(35.0^{\circ} \mathrm{N}, 135.8^{\circ} \mathrm{E}\right)$. Thirty-six plants propagated by cutting in September 2016 were grown in $1 \mathrm{~L}$ plastic pots filled with $50 \%$ weathered granite soil and $50 \%$ bark compost (v:v). The soil $\mathrm{pH}\left(\mathrm{H}_{2} \mathrm{O}\right)$ on 15 April, 2017 (before transplanting) was 5.25. The plants were transplanted into $10 \mathrm{~L}$ clay pots filled with soil that was adjusted to various $\mathrm{pH}$ levels on 15 April, 2017 using the method described below. At transplanting, the rhizosphere soil was not removed so as to not injure the roots. The plants were trimmed to a single stem, trained vertically to a height of $150 \mathrm{~cm}$, and then trained horizontally. Immediately after transplanting, the horizontally trained vines were cut at $90 \mathrm{~cm}$ and the axillary buds were pinched, and three newly emerged axillary vines were allowed to grow downward. The pots were spaced with $30 \mathrm{~cm}$ between pots and $80 \mathrm{~cm}$ between rows. A $1000 \mathrm{~mL}$ nutrient solution ( $\mathrm{pH}$ 6.2) containing $\quad 6.0 \mathrm{mM} \quad \mathrm{NH}_{4} \mathrm{NO}_{3}, \quad 6.0 \mathrm{mM} \quad\left(\mathrm{NH}_{4}\right)_{2} \mathrm{SO}_{4}$, $2.0 \mathrm{mM} \mathrm{KNO} 3,1.0 \mathrm{mM} \mathrm{Ca}\left(\mathrm{NO}_{3}\right)_{2}, 1.5 \mathrm{mM} \mathrm{K}_{2} \mathrm{HPO}_{4}$, $3.0 \mathrm{mM} \mathrm{CaCl}_{2}, 2.0 \mathrm{mM} \mathrm{MgSO}$, and $1.0 \mathrm{mM} \mathrm{K}_{2} \mathrm{SO}_{4}$ was applied to each plant once a week, and the plants were irrigated daily. The side windows of the greenhouse were opened to allow air ventilation at temperatures above $30^{\circ} \mathrm{C}$, and the minimum temperature in winter was maintained above $8^{\circ} \mathrm{C}$ by heating.

\section{Soil pH treatment}

The plants were transplanted to soil adjusted to four $\mathrm{pH}$ levels (pH 3.5, 4.5, 5.5, and 6.5) using sulfuric acid or calcium carbonate. The soil consisted of $50 \%$ weathered granite soil and 50\% bark compost (v:v). The soil was sampled immediately after transplanting and airdried for several days at room temperature. For $10 \mathrm{~g}$ of this air-dried soil, $25 \mathrm{~mL}$ of distilled water was added, and the mixture was shaken for $1 \mathrm{~h}$. Then, it was left for 30 minutes before the $\mathrm{pH}$ was measured with a $\mathrm{pH}$ meter (IM-22P; DKK-TOA Co., Tokyo, Japan). The soil $\mathrm{pH}$ values were $3.58,4.51,5.39$, and 6.73 for the target soil $\mathrm{pH}$ levels of $3.5,4.5,5.5$, and 6.5 , respectively (Table 1).

To monitor the soil $\mathrm{pH}$ change, one plant per treatment was exclusively used for continuous $\mathrm{pH}$ monitoring. The soil was sampled at a depth of $14-16 \mathrm{~cm}$ and $6-8 \mathrm{~cm}$ from the main vines twice a month until 3 July, and the soil $\mathrm{pH}$ was measured using the same method as above. According to the results of the $\mathrm{pH}$ monitoring,
Table 1. Soil $\mathrm{pH}$ on 15 April and 28 August.

\begin{tabular}{ccc}
\hline \hline \multicolumn{3}{c}{ Soil pH } \\
\hline Level & $\begin{array}{c}15 \text { April }^{\mathrm{z}} \\
\text { (at transplanting) }\end{array}$ & $\begin{array}{c}28 \text { August }^{\mathrm{y}} \\
\text { (after harvest) }\end{array}$ \\
\hline 3.5 & 3.58 & $4.09 \mathrm{~b}$ \\
4.5 & 4.51 & $4.39 \mathrm{~b}$ \\
5.5 & 5.39 & $4.90 \mathrm{a}$ \\
6.5 & 6.73 & $5.09 \mathrm{a}$ \\
\hline
\end{tabular}

z: Soil was sampled once for each treatment $(n=1)$.

${ }^{y}$ : Different letters within a column indicate statistical differences by Tukey's test at $P<0.05(\mathrm{n}=8)$.

sulfuric acid or calcium carbonate was added with irrigation water to maintain the $\mathrm{pH}$ at the target levels.

\section{Measurements}

The number of flowers per fruit-bearing vine was recorded from 14 May to 25 June, and artificial pollination was conducted at 12:00-13:00 h (3-4 hours after flowering) using a paint brush with fresh pollen. One week after pollination, the number of fruit per fruitbearing vine was counted, and the number of fruit per vine was reduced to four by fruit thinning. To prevent fruit from dropping to the ground, each fruit peduncle was tied to the vine with thread. Mature fruit that had abscised from vines were harvested. Immediately after harvest, the fruit weight and dimensions were measured, peel color was estimated visually at five levels (1: pale green to 5: dark purple), and the number of days after pollination to harvest (DAP) was recorded. After 10 days of storage at $25^{\circ} \mathrm{C}$, the peel color was estimated again, and the degree of wrinkling was estimated visually at five levels (1: no wrinkles to 5: severe wrinkles). Peel weight was recorded and the percentage of juice weight per fruit weight, titratable acidity (TA), and total soluble solid (TSS) content were measured using the methods described by Kondo and Higuchi (2013a). The sugar/acid ratio (TSS/TA) was calculated accordingly.

The vine length, numbers of nodes and leaves, and costa length of each leaf on one vine per plant were measured every two weeks until 24 June. The total leaf area was estimated based on the costa length using the calibration described by Kondo and Higuchi (2012). The leaf/fruit ratio, the leaf/flower ratio, and the leaf area per flower were calculated. The relative chlorophyll contents (SPAD index) of mature leaves at the tenth nodes from the base of the downward axillary vines were measured using a chlorophyll meter (SPAD-502Plus; Konica Minolta Sensing, Inc., Osaka, Japan) on 19 June and 21 July. On the same day, the maximum quantum yield of photosystem II $(\mathrm{Fv} / \mathrm{Fm})$ of the same mature leaves was measured using a chlorophyll fluorometer (OS-30p; Opti-Sciences, Hudson, $\mathrm{NH}, \mathrm{USA})$ at 10:00-14:00 h. The photosynthetic rate, 
transpiration rate, and stomatal conductance of the above leaves were measured using a portable gas exchange system (LI-6400; LI-COR Inc., Lincoln, NE, USA) at 10:00-14:00 h on 21 July. The measurement conditions were $1200 \mu \mathrm{mol} \cdot \mathrm{m}^{-2} \cdot \mathrm{s}^{-1}$ PPFD, $380 \mathrm{ppm}$ $\mathrm{CO}_{2}, 30^{\circ} \mathrm{C}$ block temperature, and $350 \mu \mathrm{mol} \cdot \mathrm{s}^{-1}$ flow rate. On the same day, leaf water potential was measured using a pressure chamber (Model 3000; Soilmoisture Equipment Corp., Santa Barbara, CA, USA) at 10:00-14:00 h. Roots were rinsed with water to remove soil on August 28, and the root dry weight was measured after oven-drying at $70^{\circ} \mathrm{C}$ for 3 days.

Leaves at the tenth nodes from the base of the downward axillary vines were sampled on August 16, and leaf $\mathrm{N}, \mathrm{P}$, potassium $(\mathrm{K})$, calcium $(\mathrm{Ca})$, magnesium $(\mathrm{Mg})$, iron $(\mathrm{Fe})$, manganese $(\mathrm{Mn})$, and zinc $(\mathrm{Zn})$ contents were measured using the methods described by Kondo and Higuchi (2013b).

\section{Statistical analysis}

The four treatments were arranged in a randomized block design with eight replications. The data were analyzed by randomized block analysis of variance (ANOVA), and data exhibiting statistical differences among treatments were subjected to further analysis using Tukey's test $(P<0.01$ or 0.05$)$.

\section{Results and Discussion}

\section{Soil $p H$}

The soil $\mathrm{pH}$ values in the $\mathrm{pH} 3.5,4.5$, and 5.5 treatments did not fluctuate largely, although that at $\mathrm{pH} 5.5$ was a little lower than the target level (Fig. 1). The mean values were $3.77 \pm 0.05,4.44 \pm 0.09$, and $5.14 \pm$
0.11 , respectively. The mean value for $\mathrm{pH} 6.5$ treatment was $6.48 \pm 0.17$ and this was almost the same as the target level, while the soil $\mathrm{pH}$ fluctuated. The soil $\mathrm{pH}$ values sampled from all plants after harvest (on August 28) were $4.09 \pm 0.13,4.39 \pm 0.15,4.90 \pm 0.28$, and $5.09 \pm 0.58$, respectively (Table 1 ).

\section{Vegetative growth \& physiological responses}

The vines elongated similarly in all $\mathrm{pH}$ treatments within the first four weeks (Fig. 2). However, after 27 May, the vines in the $\mathrm{pH} 6.5$ treatment became shorter than those of the other treatments. The vine length at a $\mathrm{pH}$ of 4.5 tended to be longest. Leaf area and numbers

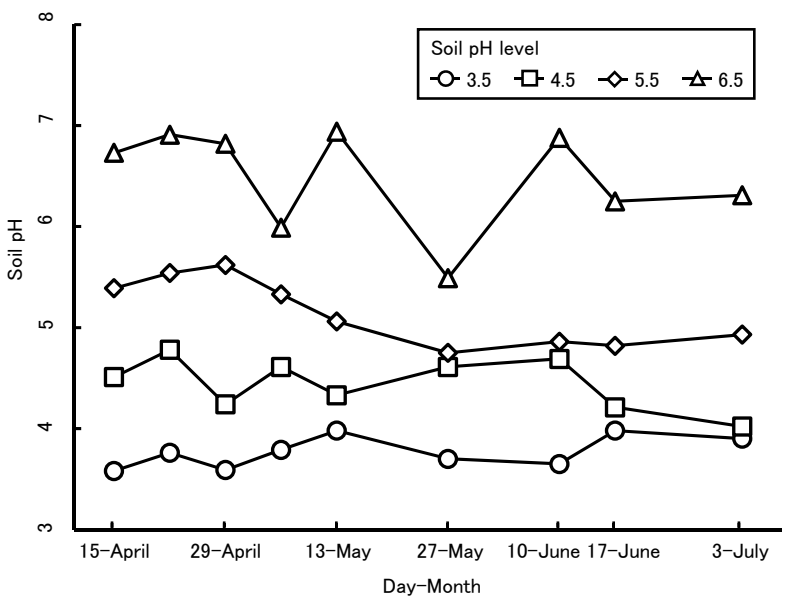

Fig. 1. Changes in soil $\mathrm{pH}$ after passion fruit transplantation. Soil $\mathrm{pH}$ mean values for the treatments were $3.77 \pm 0.05$ (circles), $4.44 \pm 0.09$ (squares), $5.14 \pm 0.11$ (diamonds), and $6.48 \pm 0.17$ (triangles).
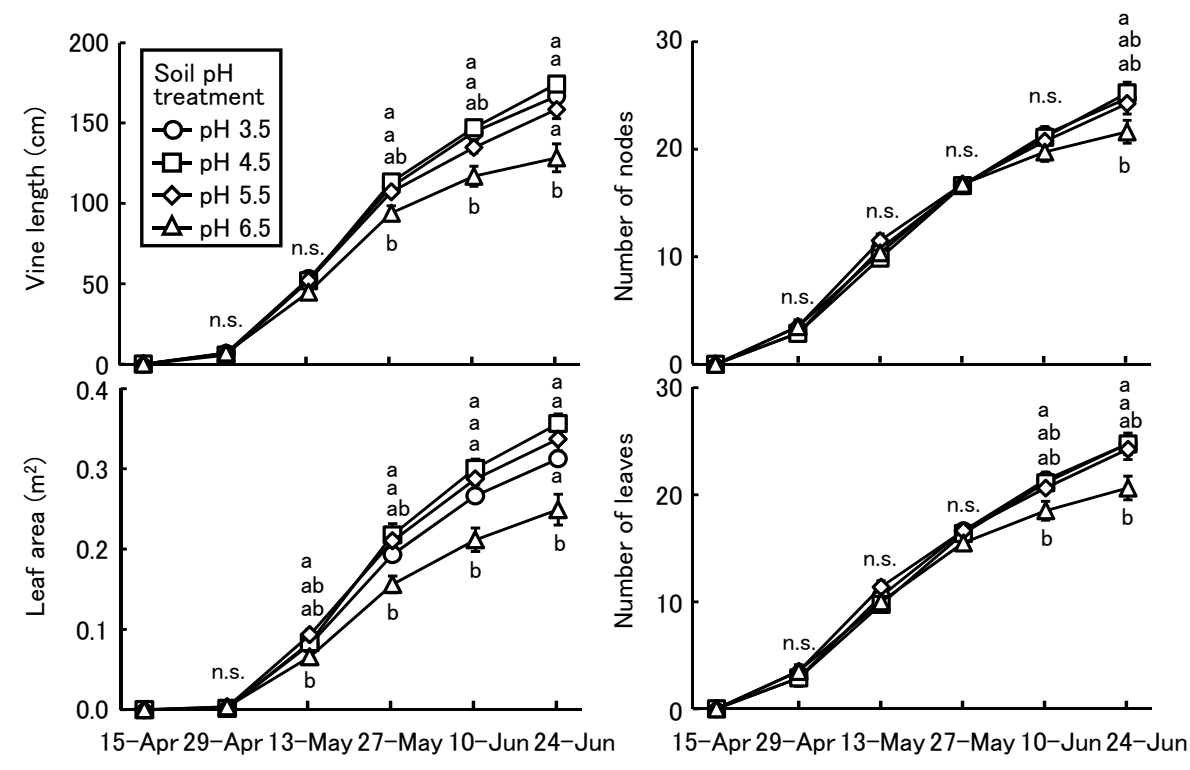

Day-Month

Fig. 2. Changes in vine length, leaf area, and the numbers of nodes and leaves after transplanting of 'Summer Queen' passion fruit to different $\mathrm{pH}$ soils within 3.5-6.5. Different letters within the same date indicate statistical differences by Tukey's-test at $P<0.05(\mathrm{n}=8)$. Vertical bars indicate SE. Source: Niwayama and Higuchi, 2017, Res. Trop. Agr. 10 [Ext. 2]: 9-10. 
Table 2. Effects of soil $\mathrm{pH}$ on photosynthetic rate, transpiration rate, stomatal conductance, and leaf water potential of 'Summer Queen' passion fruit.

\begin{tabular}{cccccc}
\hline \hline $\begin{array}{c}\text { Soil } \mathrm{pH} \\
\text { treatment }\end{array}$ & $\begin{array}{c}\text { Photosynthetic rate } \\
\left(\mu \mathrm{mol} \mathrm{CO} \mathrm{m}^{-2} \cdot \mathrm{s}^{-1}\right)\end{array}$ & $\begin{array}{c}\text { Transpiration rate } \\
\left(\mathrm{mmol} \mathrm{H}_{2} \mathrm{O} \mathrm{m}^{-2} \cdot \mathrm{s}^{-1}\right)\end{array}$ & $\begin{array}{c}\text { Stomatal conductance } \\
\left(\mathrm{mol} \mathrm{H}_{2} \mathrm{O} \mathrm{m}^{-2} \cdot \mathrm{s}^{-1}\right)\end{array}$ & $\begin{array}{c}\text { Leaf water } \\
\text { potential }\end{array}$ & $\begin{array}{c}\text { Root dry weight } \\
(\mathrm{g})\end{array}$ \\
\hline 3.5 & $14.92 \mathrm{a}$ & $3.74 \mathrm{a}$ & $0.15 \mathrm{a}$ & $-0.48 \mathrm{a}$ & $9.04 \mathrm{a}$ \\
4.5 & $12.99 \mathrm{ab}$ & $3.07 \mathrm{a}$ & $0.13 \mathrm{a}$ & $-0.49 \mathrm{a}$ & $11.38 \mathrm{a}$ \\
5.5 & $12.42 \mathrm{ab}$ & $2.82 \mathrm{a}$ & $0.11 \mathrm{a}$ & $-0.57 \mathrm{a}$ & $10.52 \mathrm{a}$ \\
6.5 & $8.76 \mathrm{~b}$ & $1.97 \mathrm{a}$ & $0.07 \mathrm{a}$ & $-0.90 \mathrm{~b}$ & $6.75 \mathrm{a}$ \\
\hline
\end{tabular}

Different letters within a column indicate statistical differences by Tukey's test at $P<0.05(\mathrm{n}=8)$.

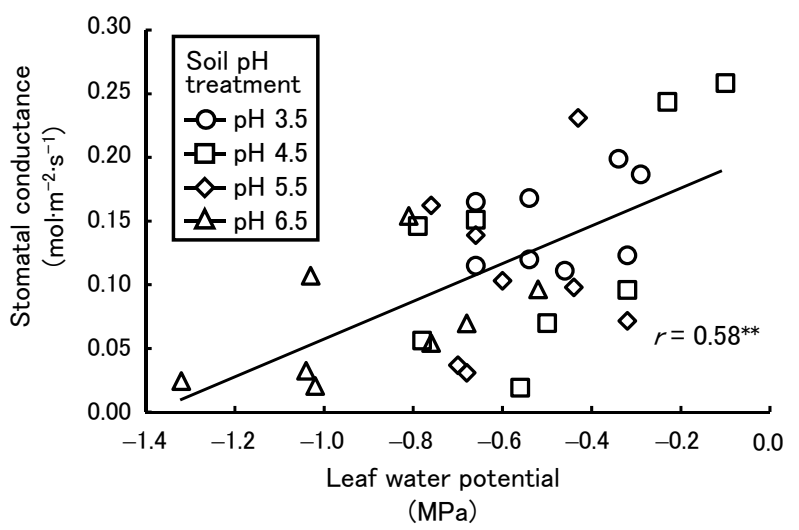

Fig. 3. Relationship between stomatal conductance and leaf water potential after transplanting of 'Summer Queen' passion fruit to different $\mathrm{pH}$ soils from 3.5-6.5.**: significance at $P<0.01$.

of nodes and leaves were smallest at $\mathrm{pH} 6.5$, at which the photosynthetic rate and leaf water potential were lowest, and transpiration rate and stomatal conductance also tended to be low (Table 2). In addition, the root dry weight tended to be lightest at $\mathrm{pH}$ 6.5. The inadequate root mass at pH 6.5 likely led to water deficiencies in the plants. Stomatal conductance was highly correlated with leaf water potential in all treatments (Fig. 3), and the photosynthetic rate and transpiration rate depended on stomatal conductance (Fig. 4). These results suggest that stomatal closure caused by water deficiency lowered the photosynthetic rate in the $\mathrm{pH} 6.5$ treatment. A decrease in the photosynthetic rate may have inhibited vegetative growth at $\mathrm{pH} 6.5$.

Vegetative growth was similar among the $\mathrm{pH} 3.5-5.5$ treatments (Fig. 2). In general, acidic soil such as pH 3.5-5.5 generally inhibits plant growth (e.g. Doss and Lund, 1975). On the other hand, some plants are known to prefer acidic soil. For instance, tea plants grown in soils at $\mathrm{pH} 3.5$ exhibited the highest dry weight (Fung and Wong, 2002). In the blueberry, the optimum range of soil $\mathrm{pH}$ has been reported to be 4.0 5.2 (Harmer, 1945). Passion fruit can also grow in soil with a $\mathrm{pH}$ of $3.5-5.5$, and it prefers the acidic soil.

The SPAD index on 19 June was lowest at $\mathrm{pH} 6.5$ (Table 3). On 21 July, the SPAD index tended to be lowest at $\mathrm{pH} 6.5$, although Fv/Fm was not affected by soil $\mathrm{pH}$. Therefore, the reduction in the SPAD index at

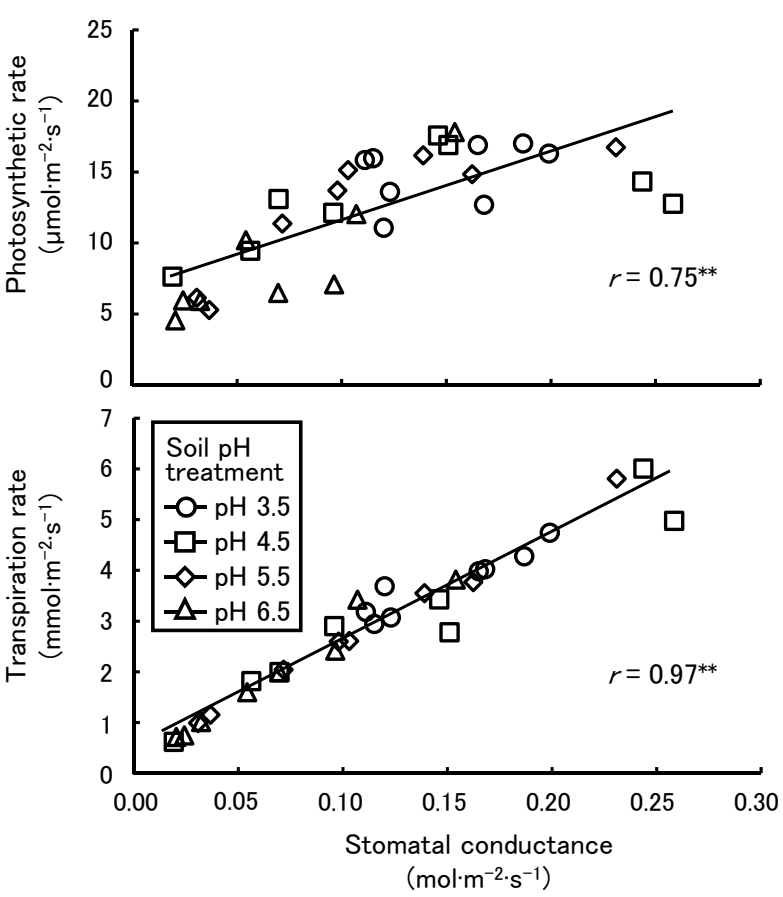

Fig. 4. Relationships of photosynthetic rate and transpiration rate to stomatal conductance after transplanting of 'Summer Queen' passion fruit to different $\mathrm{pH}$ soils from 3.5-6.5. **: significance at $P<0.01$.

Table 3. Effects of soil $\mathrm{pH}$ on the SPAD index and Fv/Fm of 'Summer Queen' passion fruit.

\begin{tabular}{cccccc}
\hline \hline \multirow{2}{*}{$\begin{array}{c}\text { Soil } \mathrm{pH} \\
\text { treatment }\end{array}$} & \multicolumn{2}{c}{ 19 June } & & \multicolumn{2}{c}{21 July } \\
\cline { 2 - 3 } \cline { 5 - 6 } & SPAD index & Fv/Fm & & SPAD index & Fv/Fm \\
\hline 3.5 & $58.1 \mathrm{a}$ & $0.79 \mathrm{a}$ & & $63.2 \mathrm{a}$ & $0.80 \mathrm{a}$ \\
4.5 & $55.5 \mathrm{ab}$ & $0.77 \mathrm{a}$ & & $63.5 \mathrm{a}$ & $0.81 \mathrm{a}$ \\
5.5 & $55.2 \mathrm{ab}$ & $0.77 \mathrm{a}$ & & $60.6 \mathrm{a}$ & $0.81 \mathrm{a}$ \\
6.5 & $52.2 \mathrm{~b}$ & $0.75 \mathrm{a}$ & & $55.6 \mathrm{a}$ & $0.80 \mathrm{a}$ \\
\hline
\end{tabular}

Different letters within a column indicate statistical differences by Tukey's test at $P<0.05(\mathrm{n}=8)$.

pH 6.5 was unlikely to be caused by photoinhibition, but may have been related to mineral absorption. Kondo et al. (2017) reported that the SPAD index decreased as soil $\mathrm{pH}$ increased in passion fruit. Deficiencies in chlorophyll content could partially explain the decrease in the photosynthetic rate at $\mathrm{pH}$ 6.5. 
Niwayama and Higuchi (2018) reported that strongly acidic soil ( $\mathrm{pH} 3.5)$ promoted the recovery of passion fruit root growth. However, in this study, dry root weight did not differ significantly between $\mathrm{pH} 3.5-5.5$ (Table 2).

\section{Numbers of flowers and fruits}

The number of flowers was not affected by soil $\mathrm{pH}$ from 14 May to 15 June (Table 4). After 16 June, the number of flowers increased as soil $\mathrm{pH}$ decreased. The number of fruits was smallest at $\mathrm{pH} 6.5$ after 1 June, although that was not affected by soil $\mathrm{pH}$ from 14 May to 31 May (Table 5). The fruit-set percentage from 14 May to 15 June was lowest at $\mathrm{pH} 6.5$, while that after 16 June was lowest at pH 3.5 (Table 6). The total numbers of flowers and fruits during the flowering period were lower at pH 6.5 (Table 7). The total fruit-set percentage was lower at $\mathrm{pH} 3.5$ and 6.5. The leaf/flower ratio was not affected by soil $\mathrm{pH}$. Conversely, the leaf area per flower was smallest at $\mathrm{pH} 6.5$. At $\mathrm{pH}$ 6.5, and the decrease in vegetative growth (Fig. 2) and photosynthetic rate (Table 2) may have reduced the leaf area per flower. The small leaf area per flower at pH 6.5 may have lowered the numbers of flowers and fruits, as well as the fruit-set percentage. At $\mathrm{pH} 3.5$, the number of flowers was highest after 16 June (Table 4), and leaf area was similar among the $\mathrm{pH} 3.5-5.5$ treatments (Fig. 2). Therefore, the relative increase in the number of flowers at pH 3.5 may have caused the small leaf area per flower (Table 7), resulting in a reduction in the fruit-set percentage after 16 June (Table 6).

The percentage of upright style flowers, which are incapable of fruit-set (e.g., Ishihata, 1981), increased at pH 3.5 after 16 June (Table 8), suggesting that the higher frequency of upright style flowers was another reason for the low fruit-set percentage after 16 June.

\section{Fruit quality}

Fruit in the $\mathrm{pH} 4.5$ and 5.5 treatments were heavier and larger than the fruit in the other treatments (Table 9). Peel color after ripening was better at a $\mathrm{pH}$ of 4.5 and 5.5, although the peel color immediately after harvesting was not affected by soil $\mathrm{pH}$. TA was lower and TSS was higher at $\mathrm{pH} 4.5$ and 5.5 than the other treatments, and the sugar/acid ratio was highest at $\mathrm{pH} 4.5$
(Table 10). Conversely, at $\mathrm{pH} 6.5$, the peel color after ripening was worse and peel wrinkling was more severe, and peel weight was the lightest among the treatments. The juice percentage increased as the soil $\mathrm{pH}$ increased. The leaf/fruit ratio was higher at $\mathrm{pH} 3.5$ and 4.5. In a previous report (Kondo and Higuchi, 2011), passion fruit weight and dimensions, as well as the sugar/acid ratio, increased and peel color improved as

Table 4. Changes in the number of flowers per fruit bearing vine of 'Summer Queen' passion fruit.

\begin{tabular}{cccc}
\hline \hline \multirow{2}{*}{$\begin{array}{c}\text { Soil } \mathrm{pH} \\
\text { treatment }\end{array}$} & \multicolumn{3}{c}{ The number of flowers } \\
\cline { 2 - 4 } & 14 May-31 May & 1 June-15 June & 16 June-25 June \\
\hline 3.5 & $5.25 \mathrm{a}$ & $6.54 \mathrm{a}$ & $2.71 \mathrm{a}$ \\
4.5 & $4.75 \mathrm{a}$ & $6.79 \mathrm{a}$ & $2.00 \mathrm{ab}$ \\
5.5 & $5.04 \mathrm{a}$ & $6.46 \mathrm{a}$ & $1.58 \mathrm{bc}$ \\
6.5 & $4.71 \mathrm{a}$ & $6.04 \mathrm{a}$ & $1.13 \mathrm{c}$ \\
\hline
\end{tabular}

Different letters within a column indicate statistical differences by Tukey's test at $P<0.05(\mathrm{n}=24)$.

Table 5. Changes in the number of fruits per fruit bearing vine of 'Summer Queen' passion fruit.

\begin{tabular}{cccc}
\hline \hline \multirow{2}{*}{$\begin{array}{c}\text { Soil } \mathrm{pH} \\
\text { treatment }\end{array}$} & \multicolumn{3}{c}{ The number of fruits } \\
\cline { 2 - 4 } & 14 May-31 May & 1 June-15 June & 16 June-25 June \\
\hline 3.5 & $4.88 \mathrm{a}$ & $4.79 \mathrm{ab}$ & $1.88 \mathrm{a}$ \\
4.5 & $4.54 \mathrm{a}$ & $5.33 \mathrm{a}$ & $1.75 \mathrm{a}$ \\
5.5 & $4.79 \mathrm{a}$ & $4.92 \mathrm{ab}$ & $1.46 \mathrm{ab}$ \\
6.5 & $4.17 \mathrm{a}$ & $4.00 \mathrm{~b}$ & $0.88 \mathrm{~b}$ \\
\hline
\end{tabular}

Different letters within a column indicate statistical differences by Tukey's test at $P<0.05(\mathrm{n}=24)$.

Table 6. Changes in the fruit-set percentage of 'Summer Queen' passion fruit.

\begin{tabular}{cccc}
\hline \hline \multirow{2}{*}{$\begin{array}{c}\text { Soil } \mathrm{pH} \\
\text { treatment }\end{array}$} & \multicolumn{3}{c}{ Fruit-set percentage (\%) } \\
\cline { 2 - 4 } & 14 May-31 May & 1 June-15 June & 16 June-25 June \\
\hline 3.5 & $93.6 \mathrm{ab}$ & $73.2 \mathrm{bc}$ & $70.3 \mathrm{~b}$ \\
4.5 & $97.3 \mathrm{a}$ & $80.0 \mathrm{a}$ & $93.3 \mathrm{a}$ \\
5.5 & $95.8 \mathrm{ab}$ & $77.1 \mathrm{ab}$ & $94.6 \mathrm{a}$ \\
6.5 & $90.9 \mathrm{~b}$ & $67.1 \mathrm{c}$ & $80.8 \mathrm{ab}$ \\
\hline
\end{tabular}

Different letters within a columun indicate statistical differences by Fisher's exact test $P<0.05$.

Table 7. Effects of soil $\mathrm{pH}$ on the total numbers of flowers and fruits per fruit bearing vine, total fruit-set percentage, leaf/flower ratio, and leaf area per flower of 'Summer Queen' passion fruit.

\begin{tabular}{cccccc}
\hline \hline $\begin{array}{c}\text { Soil } \mathrm{pH} \\
\text { treatment }\end{array}$ & $\begin{array}{c}\text { Number of } \\
\text { flowers }\end{array}$ & Number of fruits & $\begin{array}{c}\text { Fruit-set } \\
(\%)\end{array}$ & Leaf/flower ratio & $\begin{array}{c}\text { Leaf area per flower } \\
\left(\mathrm{m}^{2}\right)\end{array}$ \\
\hline 3.5 & $14.46 \mathrm{a}$ & $11.50 \mathrm{a}$ & $80.00 \mathrm{~b}$ & $1.74 \mathrm{a}$ & $0.022 \mathrm{bc}$ \\
4.5 & $13.50 \mathrm{a}$ & $11.58 \mathrm{a}$ & $87.97 \mathrm{a}$ & $1.85 \mathrm{a}$ & $0.027 \mathrm{a}$ \\
5.5 & $13.25 \mathrm{a}$ & $11.33 \mathrm{a}$ & $86.62 \mathrm{a}$ & $1.88 \mathrm{a}$ & $0.026 \mathrm{ab}$ \\
6.5 & $11.54 \mathrm{~b}$ & $8.79 \mathrm{~b}$ & $77.57 \mathrm{~b}$ & $1.75 \mathrm{a}$ & $0.021 \mathrm{c}$ \\
\hline
\end{tabular}

Different letters within a column indicate statistical differences by Tukey's test at $P<0.05$ (number of flowers and fruits: $\mathrm{n}=24$, leaf area per flower and leaf/flower ratio: $n=8$ ) and by Fisher's exact test (fruit-set). 
the leaf/fruit ratio increased, and an increase in photosynthate per fruit may improve fruit quality. The plants grown in soil with a $\mathrm{pH}$ of 4.5 grew well (Fig. 2) and the leaf/fruit ratio was higher, suggesting that high assimilation may improve fruit weight and dimensions, peel color, and the sugar/acid ratio. The fruit quality at $\mathrm{pH} 5.5$ was as high as that at $\mathrm{pH} 4.5$. In the $\mathrm{pH} 5.5$ treatment, the lower $\mathrm{pH}$ value than the target level (Fig. 1) was likely to positively affect fruit quality. Meanwhile,

Table 8. Changes in the percentage of upright style flower of 'Summer Queen' passion fruit.

\begin{tabular}{cccc}
\hline \hline \multirow{2}{*}{$\begin{array}{c}\text { Soil } \mathrm{pH} \\
\text { treatment }\end{array}$} & \multicolumn{2}{c}{ The percentage of upright style flowers (\%) } \\
\cline { 2 - 4 } & 14 May-31 May & 1 June-15 June & 16 June-25 June \\
\hline 3.5 & $0.00 \mathrm{a}$ & $0.00 \mathrm{a}$ & $21.54 \mathrm{a}$ \\
4.5 & $0.00 \mathrm{a}$ & $0.00 \mathrm{a}$ & $2.08 \mathrm{~b}$ \\
5.5 & $0.00 \mathrm{a}$ & $0.00 \mathrm{a}$ & $2.63 \mathrm{~b}$ \\
6.5 & $0.00 \mathrm{a}$ & $0.00 \mathrm{a}$ & $0.00 \mathrm{~b}$ \\
\hline
\end{tabular}

Different letters within a columun indicate statistical differences by Fisher's exact test $P<0.05$. fruit quality decreased at $\mathrm{pH} 3.5$, although the leaf/fruit ratio at $\mathrm{pH} 3.5$ was as high as that at $\mathrm{pH} 4.5$. At $\mathrm{pH} 3.5$, the number of flowers after 16 June was highest (Table 4) and the leaf area per flower was smaller (Table 7). These results suggest that relatively excess flowering at $\mathrm{pH} 3.5$ caused the consumption of photosynthate and a relative reduction in matter distribution to the fruit, resulting in a deterioration in fruit quality.

It was reported that acid content decreased and TSS increased as DAP increased (Shiomi et al., 1996; Macha et al., 2006). In this study, however, TA was highest and TSS was lowest at pH 6.5, although DAP was longer at $\mathrm{pH} 3.5$ and 6.5. The leaf/fruit ratio at pH 6.5 was lowest (Table 10) where the shortage of matter distribution into fruit was likely to delay ripening, resulting in a longer DAP.

\section{Leaf mineral contents}

Leaf $\mathrm{N}, \mathrm{Mn}$, and $\mathrm{Zn}$ contents decreased as soil $\mathrm{pH}$ increased (Table 11). Similarly, Kondo et al. (2017) reported that leaf $\mathrm{Mn}$ and $\mathrm{Zn}$ contents decreased as soil

Table 9. Effects of soil $\mathrm{pH}$ on fruit weight, dimensions, peel color, wrinkle degree, and peel weight of 'Summer Queen' passion fruit.

\begin{tabular}{|c|c|c|c|c|c|c|c|}
\hline \multirow{2}{*}{$\begin{array}{l}\text { Soil pH } \\
\text { treatment }\end{array}$} & \multirow{2}{*}{$\begin{array}{l}\text { Weight } \\
(\mathrm{g})\end{array}$} & \multirow{2}{*}{$\begin{array}{l}\text { Length } \\
(\mathrm{mm})\end{array}$} & \multirow{2}{*}{$\begin{array}{l}\text { Diameter } \\
(\mathrm{mm})\end{array}$} & \multicolumn{2}{|c|}{ Peel color ${ }^{z}$} & \multirow{2}{*}{$\begin{array}{l}\text { Wrinkle } \\
\text { degree }^{\mathrm{y}}\end{array}$} & \multirow{2}{*}{$\begin{array}{c}\text { Peel weight } \\
\text { (g) }\end{array}$} \\
\hline & & & & At Harvest & After 10-day storage & & \\
\hline 3.5 & $87.5 \mathrm{~b}$ & $65.1 \mathrm{~b}$ & $60.5 \mathrm{~b}$ & $2.6 \mathrm{a}$ & $4.3 \mathrm{ab}$ & $1.5 \mathrm{~b}$ & $41.7 \mathrm{~b}$ \\
\hline 4.5 & $94.6 \mathrm{a}$ & $67.9 \mathrm{a}$ & $63.0 \mathrm{a}$ & $2.9 \mathrm{a}$ & $4.6 \mathrm{a}$ & $1.3 \mathrm{~b}$ & $44.5 \mathrm{a}$ \\
\hline 5.5 & $95.1 \mathrm{a}$ & $67.6 \mathrm{a}$ & $62.7 \mathrm{a}$ & $2.8 \mathrm{a}$ & $4.6 \mathrm{a}$ & $1.5 \mathrm{~b}$ & $43.7 \mathrm{ab}$ \\
\hline 6.5 & $81.3 \mathrm{c}$ & $66.5 \mathrm{ab}$ & $60.0 \mathrm{~b}$ & $2.5 \mathrm{a}$ & $4.2 \mathrm{~b}$ & $2.0 \mathrm{a}$ & $35.5 \mathrm{c}$ \\
\hline
\end{tabular}

Different letters within a column indicate statistical differences by Tukey's test at $P<0.01(\mathrm{n}=90,89,84$, and 83 for soil $\mathrm{pH} 3.5,4.5,5.5$, and 6.5 treatments, respectively).

z: Peel color was estimated visually at 5 levels (1: pale green to 5 : dark purple).

y: Wrinkle degree was estimated visually at 5 levels (1: no wrinkles to 5 : severe wrinkles).

Table 10. Effects of soil $\mathrm{pH}$ on titratable acidity (TA), total soluble solid content (TSS), sugar/acid ratio, juice percentage, leaf/fruit ratio, and days after pollination to harvest (DAP) of 'Summer Queen' passion fruit.

\begin{tabular}{cccccccc}
\hline \hline Soil $\mathrm{pH}$ treatment & TA $(\%)$ & TSS $\left({ }^{\circ}\right.$ Brix $)$ & Sugar/acid ratio & Juice percentage $(\%)$ & Leaf/fruit ratio & DAP \\
\hline 3.5 & $2.74 \mathrm{ab}$ & $14.3 \mathrm{~b}$ & $5.3 \mathrm{bc}$ & $35.1 \mathrm{~b}$ & $6.19 \mathrm{a}$ & $62.3 \mathrm{a}$ \\
4.5 & $2.62 \mathrm{~b}$ & $16.2 \mathrm{a}$ & $6.4 \mathrm{a}$ & $36.2 \mathrm{ab}$ & $6.19 \mathrm{a}$ & $59.9 \mathrm{~b}$ \\
5.5 & $2.72 \mathrm{~b}$ & $15.7 \mathrm{a}$ & $5.9 \mathrm{ab}$ & $37.0 \mathrm{a}$ & $6.06 \mathrm{ab}$ & $59.8 \mathrm{~b}$ \\
6.5 & $2.93 \mathrm{a}$ & $13.5 \mathrm{~b}$ & $4.7 \mathrm{c}$ & $37.7 \mathrm{a}$ & $5.16 \mathrm{~b}$ & $62.4 \mathrm{a}$ \\
\hline
\end{tabular}

Different letters within a column indicate statistical differences by Tukey's test at $P<0.01$ (Data excluding leaf/fruit ratio: $\mathrm{n}=90,89,84$, and 83 for soil $\mathrm{pH} 3.5,4.5,5.5$, and 6.5 treatments, respectively; leaf/fruit ratio: $\mathrm{n}=8$ ).

Table 11. Effects of soil $\mathrm{pH}$ on the leaf mineral contents (dry weight basis) of 'Summer Queen' passion fruit.

\begin{tabular}{ccccccccc}
\hline \hline $\begin{array}{c}\text { Soil pH } \\
\text { treatment }\end{array}$ & $\begin{array}{c}\mathrm{N} \\
(\%)\end{array}$ & $\begin{array}{c}\mathrm{P} \\
(\%)\end{array}$ & $\begin{array}{c}\mathrm{K} \\
(\%)\end{array}$ & $\begin{array}{c}\mathrm{Ca} \\
(\%)\end{array}$ & $\begin{array}{c}\mathrm{Mg} \\
(\%)\end{array}$ & $\begin{array}{c}\mathrm{Fe} \\
(\mathrm{ppm})\end{array}$ & $\begin{array}{c}\mathrm{Mn} \\
(\mathrm{ppm})\end{array}$ & $\begin{array}{c}\mathrm{Zn} \\
(\mathrm{ppm})\end{array}$ \\
\hline 3.5 & $5.1 \mathrm{a}$ & $0.3 \mathrm{a}$ & $2.88 \mathrm{a}$ & $1.12 \mathrm{~b}$ & $0.2 \mathrm{~b}$ & $40.7 \mathrm{a}$ & $316 \mathrm{bc}$ & $54.4 \mathrm{a}$ \\
4.5 & $4.7 \mathrm{a}$ & $0.3 \mathrm{a}$ & $2.13 \mathrm{~b}$ & $2.35 \mathrm{a}$ & $0.2 \mathrm{ab}$ & $41.7 \mathrm{a}$ & $549 \mathrm{a}$ & $41.7 \mathrm{ab}$ \\
5.5 & $4.2 \mathrm{~b}$ & $0.3 \mathrm{a}$ & $2.23 \mathrm{~b}$ & $2.88 \mathrm{a}$ & $0.25 \mathrm{a}$ & $26.4 \mathrm{a}$ & $369 \mathrm{~b}$ & $27.5 \mathrm{bc}$ \\
6.5 & $3.9 \mathrm{~b}$ & $0.3 \mathrm{a}$ & $2.31 \mathrm{~b}$ & $2.69 \mathrm{a}$ & $0.20 \mathrm{ab}$ & $32.8 \mathrm{a}$ & $228 \mathrm{c}$ & $20.9 \mathrm{c}$ \\
\hline
\end{tabular}

Different letters within a column indicate statistical differences by Tukey's test at $P<0.05$ ( $\mathrm{n}=6,8,8$, and 6 for soil $\mathrm{pH} 3.5,4.5,5.5$, and 6.5 treatments, respectively). 
$\mathrm{pH}$ increased in passion fruit. Leaf $\mathrm{N}, \mathrm{Mn}$, and $\mathrm{Zn}$ are closely related to chlorophyll biosynthesis and photosynthesis (Mae et al., 2001; Masuda, 1988). A deficiency in these minerals may have lowered the photosynthetic rate and SPAD index at a $\mathrm{pH}$ of 6.5 (Tables 2 and 3).

Leaf $\mathrm{K}$ content was highest at $\mathrm{pH} 3.5$, while $\mathrm{Ca}$ and $\mathrm{Mg}$ contents were lowest. A previous study found that leaf $\mathrm{K}$ content and TA increased as $\mathrm{K}$ nutrient concentration increased in passion fruit (Kondo and Higuchi, 2013a). Kondo and Higuchi (2014) also reported that the leaf $\mathrm{Ca}$ content decreased and TA increased at high $\mathrm{Ca}$ concentrations in passion fruit. Similarly, our results indicated that TA increased when the leaf $\mathrm{K}$ content was high and $\mathrm{Ca}$ content was low at a soil $\mathrm{pH}$ of 3.5. Leaf $\mathrm{P}$ and $\mathrm{Fe}$ contents were not affected by soil $\mathrm{pH}$.

\section{Conclusion}

Acidic soil with a $\mathrm{pH}$ of 4.5 is recommended for producing high-quality passion fruit, although fruit quality did not differ statistically between $\mathrm{pH} 4.5$ and 5.5 . Conversely, near-neutral soil ( $\mathrm{pH}$ 6.5) resulted in decreased vegetative growth, fruit-set percentage, and fruit quality. Thus, recommendable soil for growing passion fruit should be acid such as $\mathrm{pH} 4.5$. To lower the soil $\mathrm{pH}$, the application of organic matter or acid fertilizer (e.g. ammonium sulfate) will be effective. Irrigation with rainwater is also acceptable because it is generally acid. However, extremely acidic soil (pH 3.5) will result in a decreased fruit-set percentage and fruit quality.

\section{Literature Cited}

Anderson, C. A. 1971. Effects of soil pH and calcium on yield and fruit quality of young 'Valencia' oranges. Proc. Amer. Soc. Hort. Sci. 74: 261-265.

Deshmukh, N. A., R. K. Patel, S. Okram, H. Rymbai, S. S. Roy and A. K. Jha. 2017. Passion fruit (Passiflora spp.). p. 979 1005. In: S. N. Ghosh, A. Singh and A. Thakur (eds.). Underutilized fruit crops: importance and cultivation. JAYA Publishing House, Delhi, India.

Doss, B. D. and Z. F. Lund. 1975. Subsoil pH effects on growth and yield of cotton. Agron. J. 67: 193-196.

Fung, K. F. and M. H. Wong. 2002. Effects of soil pH on the uptake of Al, F and other elements by tea plants. J. Sci. Food and Agric. 82: 146-152.

Gilmour, J. G. 1983. A guide to granadilla growing in Zimbabwe. Zimbabwe Agric. J. 80: 83-92.

Harmer, P. M. 1945. The effect of varying the reaction of organic soil on the growth and production of the domesticated blue- berry. Soil Sci. Soc. Amer. 9: 133-141.

Ishihata, K. 1981. Studies on the morphology of flowering organs and the fruit bearing in purple passion fruit, Passiflora edulis Sims. Bull. Fac. Agr., Kagoshima Univ. 31: 25-31 (In Japanese).

Katakura, Y. and H. Yokomizo. 1995. Effects of nutrient solution $\mathrm{pH}$ on the growth and nutrient uptake of highbush and rabbiteye blueberries. Japan. Soc. Soil Sci. Plant Nutr. 66: 513-519 (In Japanese with English abstract).

Kondo, T. and H. Higuchi. 2011. Effect of crop load on the acidity of passion fruit. Trop. Agr. Develop. 55: 129-134.

Kondo, T. and H. Higuchi. 2012. Effects of excess $\mathrm{NH}_{4}-\mathrm{N}$ or $\mathrm{NO}_{3}-\mathrm{N}$ fertilizer applications on leaf injury, vegetative growth, and leaf mineral contents in passion fruit. Trop. Agr. Develop. 56: 88-94.

Kondo, T. and H. Higuchi. 2013a. Acidity of passion fruit as affected by potassium fertilizer. Acta Hortic. 984: 385-391.

Kondo, T. and H. Higuchi. 2013b. Effects of excess phosphorus application on passion fruit quality. Trop. Agr. Develop. 57: 109-113.

Kondo, T. and H. Higuchi. 2014. Effects of calcium concentration in nutrient solution on passion fruit quality. Res. Trop. Agr. 7 [ext. 1]: 81-82 (In Japanese).

Kondo, T., H. Higuchi, N. Kozai and T. Ogata. 2017. Effects of neutralization of acidic soil on vegetative growth, flowering, and leaf mineral contents of passion fruit cultivated in Okinawa. Acta Hortic. 1178: 93-97.

Macha, M. M., A. K. Chowdhury, K. Nomura, M. Ide and Y. Yonemoto. 2006. Effect of temperature regime and soil moisture level on fruit quality of 'Summer Queen' passionfruit (Passiflora edulis $\times$ P. edulis $\mathrm{f}$. flavicarpa). Jpn. J. Trop. Agr. 50: 70-75.

Mae, T., H. Koyama, K. Tawaraya, T. Hara, J. Sekiya, S. Inanaga, H. Sasakawa, M. Takahashi, M. Fukami, H. Obata, Y. Watanabe, T. Matoh and M. Yamanouchi. 2001. Shokubutsuno-seiiku-to-eiyou-shisutemu (In Japanese). p. 117-183. In: S. Mori, T. Mae and T. Yoneyama (eds.). Shokubutsueiyougaku. Buneido Publishing, Tokyo.

Masuda, Y. 1988. Shokubusu-no-eiyou (In Japanese). p. 119-212. In: Y. Masuda (ed.). Shokubutsuseirigaku. Baifukan, Tokyo.

Morton, J. F. 1987. Passionfruits. p. 320-328. In: J. F. Morton (ed.). Fruits of Warm Climates. Julia F. Morton, Miami, FL, USA.

Nakasone, H. Y. and R. E. Paull. 1998. Passion-fruit. p. 270-291. In: H. Y. Nakasone and R. E. Paull (eds.). Tropical Fruits. CABI Publishing, Wallingford, Oxfordshire, UK.

Niwayama, S. and H. Higuchi. 2018. Effects of soil $\mathrm{pH}$ on the root growth of passion fruit and the mechanism of mineral uptake. Acta Hortic. 1217 (VIII ISHS Symposium on Mineral Nutrition of Fruit Crops. 27-30 June, 2017. BozenBolzano, Italy) (In press).

Shiomi, S., L. S. Wamocho and S. G. Agong. 1996. Ripening characteristics of purple passion fruit on and off the vine. Postharvest Biol. Technol. 7: 161-170. 